Slavica Anđelić ${ }^{1}$

Miloš Nikolić ${ }^{2}$

Tamara Vesić ${ }^{3}$

Faculty of Business Economics and Entrepreneurship

Belgrade, Serbia
SCIENTIFIC REVIEW ARTICLE

DOI:10.5937/ekonomika1702087A

Received: April, 11, 2017

Accepted: May, 08, 2017

\title{
STRATEGIC ADJUSTMENT OF THE COMPANY CHANGES
}

\begin{abstract}
Strategic planning, because of its emphasis on the future, implies extreme subjectivity in the development and assessment of a variety of objectives and strategies. The influence of personal values and priorities of the strategic planning is not limited to personal values and priorities of the company managers, but also other employees and the customers. Personal values and priorities, internal or external, carry with them certain advantages and disadvantages. In some cases they improve strategic planning by creating a differential advantage in the marketplace or in the costs. In contrast, they can sometimes limit the goals and strategies of the company. The company must continuously assess potential trends in personal values and priorities, and on the basis of this assessment to develop variants of the strategic plans of potential changes, taking into account the possible reactions to the same competition.

The plan allows the company to better prepare for possible changes in the environment, and the development of strategic variants prepare their business for any events before they actually do occur.
\end{abstract}

Key words: strategic planning, strategic management, company, plan and strategy.

JEL classification: L52, P41, M11

\section{СТРАТЕГИЈСКО ПРИЛАГОЪАВАЊЕ ПРЕДУЗЕТА ПРОМЕНАМА}

\begin{abstract}
Апстракт
Стратегијско планирање, због свог нагласка на будућности, подразумева изузетну субјективност у развоју и очени разних цилева и стратегија. Утииај личних вредности и приоритета на стратегијско планирање није ограничен само на личне вредности и приоритете руководилаца предузећа,
\end{abstract}

\footnotetext{
${ }^{1}$ slavica.andjelic@indmanager.edu.rs

2nikolic2206@gmail.com

${ }^{3}$ tamara.vesic@live.com
} 
већ и осталих запослених, као и самих клијената. Личне вредности и приоритети, унутрашње или спољашње, носе са собом и одређене предности и недостатке. У неким случајевима они побољшавају стратешко планирање тако што стварају диферениијалну предност на тржишту или у трошковима. Насупрот томе, некада могу ограничити иильве и стратегије предузећа. Предузеће мора перманентно проиенивати потенцијалне трендове у личним вредностима и приоритетима, и на бази те оиене развијати варијанте стратешких планова потенцијалних промена, водећи рачуна о могућим реакцијама конкурениије на исте.

План предузећу омогућава да се што боље припреми за могуће промене у окружењу, и да развијањем стратешких варијанти припреми своје пословање за евентуалне догађаје пре него што до юих заправо и дође.

Кључне речи: стратегијско планирање, стратегијски менацмент, предузеће, план и стратегија

\section{Introduction}

Management as a permanent action on the basis of decisions made planning company strives not only to adapt, but also to actively influence the conditions in which it carries out its business activity. Planning company seeks to eliminate the adverse impacts on their business activity. Although a number of factors affecting the company beyond its control, without planning the events with which the company is facing would be left to the case - a concurrence of circumstances with a positive or negative outcome for the company. Experience teaches us that a number of events would not have occurred at all if it were not planning activities of the company. Planning means that the company is in a dilemma whether to leave him water events in the future or that seeks to create or at least influence on their future consciously defines the different alternatives. A company that plans ready for the changes, while a company that does not plan permanent unsuccessfully resolved "unforeseen problems". Planning means thinking systematically about the future of the company, with the emphasis that it creates in the present action. Planning is creating change rather than preserving the status. This activity is for something to happen that otherwise no action planned would not happen. Planning is a continual process of making planning decisions to make changes in the relationship between the company and the environment. Planning allows the company to expand its attention outside the markets in which it performs its business activity at present.

Planning is a good approach to the time and space. The time horizon is a time limit on a predictable share of the unpredictable future. Long-term planning does not mean the same interval for all companies.

Belief in the planning is based on the assumption that it increases control of the future and the ability to react to events that can not be controlled. The dilemma is planned or being planned. The intended business objectives will not be achieved if it fails to take appropriate action, and if it is likely to take positive outcomes povećava.Ukoliko the company wants to have some control over events, it must be planned. If the activity is not planned defense company must react to events in the middle. Planning company may 
seek to reduce the impact of changes to his position in the middle, to reduce delays in response and, finally, as must act to reduce the costs of response.

Although planning is future-oriented, it allows you to support the current reality of the decision, based on which the action is undertaken immediately. It allows to assess the decisions "mature" to be made today, and that it is better to postpone for tomorrow. The current decision is based on planned objectives. This reduces the ability to create a crisis situation for which they found a partial solution, but it is not possible to avoid negative consequences for the enterprise mobility.

\section{Strategic planning}

Strategic planning is necessary due to changes in the environment which in various ways affect the performance of the company. Very often changes affect the structure of the industry that requires strategic reaction. Strategic planning allows the company to face the so-called. "Future shock" which is described as a disease of people and organizations that the future beyond, before being ready for it. "Future Shock" occurs when the tip speed of change and developments beyond the individual's ability to adapt. The necessity of strategic planning stems from the fundamental difference between passive and active response to changes in the environment, or between passive and active adjustments. Before making business decisions to initiate an active adjustment, it should be established whether these are operational, competitive or strategic changes in the middle. On the operational changes to respond by adjusting the volume of activity. In the competitive changes respond planned actions that lead to change the position of companies in the structure of the branches. On the strategic changes are responding by changing markets, technology and capacity of the company. Today, literature is treated as strategic planning framework for innovation, and as a stimulus for new products, technological processes and markets. Strategic thinking is needed is not to be taken aback effects of changes in the macro and micro environment. The problems arise when the company changes in the environment are not accompanied by customizing company adequately.

Changes in the environment can be basically positive for the company or inadequate response management can lead to a deepening mismatch between resources companies and require protection. It's in a good number of cases means that invent new relationships between assets and expertise of companies and require protection.

In strategic planning, the company faces very complex problems that can not be solved or can be somewhat simplified. They have a number of causes, it is difficult to describe, there is no right answer. Solutions to these problems are not real and false, but good or bad. There is no direct or final test for this kind of problem. Any such problem is unique. The difficulty is that planners have no right to make mistakes. Those who solve this kind of problem are responsible for the consequences, because the stocks have a large impact on the company. Nevertheless, strategic planning is the right answer for this kind of problem. Strategic plans should be "living" documents which change according to the needs of enterprises, should create scenarios and strive to achieve the future they want.

All shares of individual competitors in the industry are focused on the use of ways of gaining competitive advantage. The effectiveness of certain actions depends on the phase of the life cycle of the branch, as well as the reaction of other companies in the 
industry. Superior profitability assumes a high perceived value and / or lower costs than competitors in its delivery. One must know when it is more emphasis on perceived value, and when the lower costs.

The purpose of strategic planning is to achieve superiority over competing companies. Superiority should exist in relation to consumers, in the way of meeting their needs and to deliver superior value. The causes of superiority over the competition should look for the roots of the advantages and superior expertise and superior resources. To root advantages have resulted in a better strategic position in the market, management must have the ability to effectively and efficiently use superior expertise and superior resources. Strategic plan companies expressed direction for the future, the objective of performance and strategy. A merging of strategic vision, goals and strategies in the strategic plan.

The effectiveness of strategic planning now predominantly depends on the level of development of the strategic management of the company. Strategic planning contributes to the creation of strategic options and the choice of optimal strategy. Strategic management involves thinking, decision making and action to create competitive advantages. The concept of strategic management allows a rational approach is not only more strategic planning and realization of transformation processes in the company.

Strategic management involves three areas of activity: strategic analysis, strategic choice and strategic change. Strategic planning gives its full contribution to the strategic analysis and strategic choice. These are areas of activity covered by the sector planning in modern enterprises.

According to Drucker strategic planning, analytical thinking and preparing resources for allocation. He emphasizes that strategic planning does not deal with future decisions over the future of present decisions. The problem is that the future should be incorporated into the current thinking and action, that period should be considered and how to use the information that at present make rational decisions. For him, the real strategic plans are leading to immediate action, seeking new and better ways to achieve the objectives of the business. Strategic planning is preparing the current business for the future. Its purpose is to direct action. He points to the three essential attributes of strategic planning. The first is its orientation to basic questions the effectiveness of the company, such as the selection of the right business area. Another important attribute of strategic planning is its orientation to change the strategic position of the company. The third attribute is oriented to the growth and development of the domestic and international markets.

\section{The relative value of strategic planning is measured by its contribution:}

1. precise identification of strengths and weaknesses of the company;

2. identifying existing and potential advantages over other participants in business operations;

3. risk assessment of certain alternative courses of action, and

4. assess the internal consistency of the elements of the Strategy.

Strategic planning contributes to avoid the mistake that the allocation of origin do before you formulate strategies, and to formulate strategies and allocation of resources is performed spontaneously. Finally, strategic planning is a creative approach to the planning process that focuses on the future of present decisions. 
In strategic planning should make a distinction between the decisions that have the character of policy and strategy. Privacy (attitudes, concepts, principles or criteria) shall be taken to ensure the routing decision (making daily decisions) toward the goals. Decisions that have the character of policies ensuring consistency, economy and unique solving current problems that arise in business. They are the focus of decision-making that occur in business and which can be largely programmed. The strategy is a way to achieve the goals and objective of each new strategy seeks to achieve. These are decisions that are not structured and that can not be programmed.

A distinction is made between one-way and two-way learning. At DC learning or model of organizational learning that begins with a plan that, like any plan, seldom fully realized. Usually that is based on monitoring of the execution plan, and adjusted as new implements. This continues the trials and errors, corrections and adjustments. The DC cycle learns how to better implement the existing plan. Does not leave enough room to open itself into question. The focus is how to effectively implement a plan that you've implemented the real operation. Sooner or later, every company has to move towards strategic learning cycle, in which the focus is changing from "' how " to "' what ", ie the emphasis on the efficiency of the emphasis on efficiency. Strategic cycle involves reflecting operational performance as required by developments in the external environment. Connection between the external environment and internal organizational processes, enables management to create new business vision and priorities. New approaches are then included in the operational processes in the next operating cycle. Then two-way learning happens in the strategic and operational cycle. Working only at the strategic level, without involving the learning back to the operating cycle, is a oneway learning at the strategic level. Similarly, working only on an operational level without being able to observe whether the current operation still valid for the environment, is a one-way learning at the operational level. Transformation goes further and asks what is the purpose of the action? It links the operational and strategic levels of learning.

Long ago has argued that planning is a learning enterprise planning institutional learning. Indicates that the weight of institutional learning from individual learning. Effective individual learning is a prerequisite for the success of the company. The reason is that significant changes resulting from learning about the companies themselves and their environment. In fact, the normal decision-making process in the company is a learning process, because people change their mental models and create common models as they talk. Learn faster than competitors may be the only way to strengthen competitive advantage.

When both markets, both product and origin, turbulent and disruptive, competitive advantage must be constantly renewed. Businesses can do so only if you manage your knowledge. Therefore, it is necessary to use two means of strategic planning - planning scenarios and internal strategic analysis - to create a plan and integrate knowledge to achieve a sustainable competitive advantage in the hypercompetitive markets.

How external market-oriented, and internally-oriented company can provide focus and create a strategic plan to guide business action. But with this it is necessary to employ the organizational knowledge management prepared to use the advantages of developing the competitiveness of the market. There is no essence of competence does not give the company a competitive advantage because they can copy, replace and make irrelevant.

Companies can gain competitive advantage in the hypercompetitive markets, developing organizational knowledge through strategic planning. It enables both the 
structure and context for the development of such knowledge that is sustainable and renewable source of competitive advantage.

Strategic planning is a process that identifies the gap between existing and required skills, contributing to the company becomes a learning organization, which creates conditions for superior performance.

\section{Strategic analysis}

Most authors define analysis environment as the process of monitoring the state and changes in it to set up signals for the opportunities and risks that may affect the company's ability to achieve its business objectives. There is an opinion that the analysis of the middle has three purposes. The first contribution to enterprise policy and improve the management of information on developments in the middle, that would be well defined basic strategic questions. Another role is to help the integrated strategic planning or providing information needed by managers at both companies, and the level of SPJ to improve the overall quality of the planning and coordination of special management and the SPJ. The third role is to help the business functions that help functional managers at the company level and possibly SPJ, if any in the company, the changes that have a major impact on the results of individual business functions.

Critical information for the assessment of the current strategic position of the company are about to get on to market share, the relative growth rates of companies and markets and whether the competitive position improves or worsens. On the basis of such information it is possible to estimate the power of strategic positions of companies and to assess whether it will be in the foreseeable future to improve or deteriorate. The emphasis in monitoring changes in the middle should be on those changes that have a high probability event and a great influence on the company.

The economic analysis should determine whether the structural changes in the environment or in part. Partly reflect the important indicators in a given structure, a structural point to qualitative changes in the relations between enterprises and the environment. Economic analysis can include all levels (global, regional, national, and local) or only one of them. Changes to the higher level have implications for the lower levels. Economic analysis is a reliable information base for the analysis of sensitivity to changes in companies, or answer questions "what if?" What is important to identify market opportunities and alternative approaches to their use.

\section{The effectiveness of strategic planning}

Managers should use planning as an essential mechanism in dealing with the instability of the environment. Of course, as the situation becomes more complex, it is planning more complex. It is understandable that emphasize innovation and adaptation. It is essential to balancing the four dimensions of planning: symbolic, rational, transactional and generative. In large companies a bigger role than a symbolic planning at companies of other dimensions. Expressed instability requires more emphasis on generative planning. Assessment of future markets is an important prerequisite for timely adjustment to changes in the enterprise environment. 
Strategic planning should be introduced taking into account the culture of the company, in an effort to reflect employees as a strategic thinkers. Strategic thinkers are people who have already shown that they can think beyond today. This does not mean that only strategic thinkers participants in the process of strategic planning because the teams need people whose competence in understanding everyday tasks at the operational level. The realization of the relationship between operational considerations and strategic considerations is a critical element in the successful implementation of strategic planning.

Looking at the performance of people rather than businesses in relation to the strategy, suggests a new concept of "champions of strategic planning." This applies to practitioners involved in the strategy. These are practitioners who introduce, promote and guide the process of strategic planning in the company. It is believed that there are three roles that the champion has to do to perform traditional tasks competently and technical expert. The three roles are: development of social relations, a good interpreter of the famous alien. Champion is an expert in strategic thinking, which has specific technical and analytical skills. This helps to enable you to master the traditional roles of strategic and analytical thinker planners.

\section{Strategic control companies}

Strategic control deals with the success rate to achieve the basic strategic direction of the company, in terms of its relationship with the environment. Strategic control relies on information from several sources, but it is a greater reliance on information from external sources. Often it comes to assessing planning assumptions underlying the strategic plans. The focus of the analysis of the information on which it is possible to answer the questions: whether the company choose the right business areas, whether in them moving in the right direction and whether it works effectively.

Strategic control has a directional character due to the time lag between the initiated application of the chosen strategic options and the final results of the actions taken. The focus of the strategic control in several important areas, which can be a source of risk. The assumption of strategic control performance is good to identify the critical success factors of companies in formulating strategic plans.

It is believed that there are three styles of management in diversified businesses:

1. Strategic Planning,

2. Strategic control and

3. financial control.

\section{Conclusion}

Successful strategic planning is a kind of bridge between the company and its environment. Bridging the perceived obstacles and establishes the shortest connection to the target markets.

The system of strategic planning arises from the need for strategic management thinking. Performs the analysis and assessment of the competitive situation and to analyze branch (s) in which the enterprise conducts its business activity. Performs the 
dynamic allocation of resources based on their potential to create value. Predict new trends and phenomena of discontinuities in the economy. Management is increasingly focused on new product - market. The emphasis is increasingly placed in the research and development activity of the company. Greater attention is paid to the study of consumers and competition. The company is oriented to the domestic and international markets as a source of ideas and scope of business activities.

A larger number of authors tell the difference between long-term and strategic planning in the future observation. In long-term planning is believed to be to predict the future by extrapolating the historical growth of the company. Management believes that the performance in the future will be better than in the past. The strategic planning is not expected that the future will certainly be better than the past, nor does it believe that the past can be extrapolated into the future. In strategic planning replaces extrapolation strategic analysis (internal and external) to establish the strengths and weaknesses as well as opportunities and threats for the company.

The Company generates, its business plans, the mission in cooperation with internal and external factors. Management is the one who has to understand and predict the scope of opportunities and threats that are in the environment and taking into account the strengths and weaknesses of the company determine the way of business. The development environment is changing and management company. If a company combination of financial, material and human resources, and realizes maximize business objectives, then the launch and implementation of its activities depends on the circuit entrepreneurs, leaders and managers whose successful cooperation between the company achieves its mission.For the emergence, survival and successful business operations are important: capital, innovation and risk-taking, business ideas, and the ability to get through the planning, organization, management and control in managing the process of production.

The company is constantly faced with the opportunities that he indicated in an environment even though they are often masked the problems. At the company or the management company is that they identify, predict and determine their size and ability to adapt to changing stretegijsko companies.

\section{References}

Agrawal E. (2016) Enterprise risk management essential for survival and sustainable development of micro, small and medium enterprises, International Review No. 1-2, Visoka škola za poslovnu ekonomiju i preduzetništvo, Beograd

Anđelić S., Čukanović-Karavidić M., Karavidić S., (2015) Organizational support and institutional environment for entrepreneurship development, International Review No. 3-4, Visoka škola za poslovnu ekonomiju i preduzetništvo, Beograd.

Apenko S. (2013) Personnel and project teams leadership in the management of strategic changes in the organization, International Journal of Strategic Management and Decision Support System in Strategic Management, Faculty of Economics, University of Novi Sad, Subotica

Aston, C. (1998), The team that brought millions, Compendium, quality, Europe Jugoinspekt, no. 9-10, Belgrade. 
Babcock, D. (2010), „Management Strategies for the Cloud Revolution“ , Mc GrawHill, New York.

Camillus, C.J., Strategy as a Wicked Problem, Harvard Business Review, 2008.

Certo, L. Peter, P., Strategic Management, Concepts and Applications, Second edition, McGrow-Hill Book Company, New York, 1991.

Ćirović, M., Milisavljević, M., Pokrajac, S., Mašić, B., Heleta, M., Strateški menadžment, Naučno društvo Srbije i Univerzitet Singidunum, Beograd, 2009.

Drucker, Ph., Management, Pan Books, London, 1997.

Đuričin, D., Janošević, S., Strategija i menadžment, Ekonomski fakultet Beograd, 2007 ili 2011.

Harrigan, K. R. (2003), Declining Demand, Divestiture and Corporate Strategy, Beard Books, New York.

Janićijević N. (2008) Upravljanje organizcionim promenama, Beograd: Ekonomski fakultet.

Milisavljević M. (2003) Strategic Changes in the Companies, Serbian Scientific Rewiew No. 31/32, Beograd

Mitrović S., Grubić-Nešić L. (2014), Changes in the management system as a basic for corporate restructuring, Zbornik radova sa Treće međunarodne konferencije "Employment, education and entrepreneurship", Belgrade

N. Figar, Upravljanje resursima preduzeća, Ekonomski fakultet u Nišu, 2007.

Petrović B. (2001) Strategijske promene i konkurentnost preduzeća, Ekonomika poljoprivrede Br. 1-4, Institutu za spoljnu trgovinu, Beograd

Slatter, S. i D. Lovett, (1999), Corporate Turnaround, Penguin Books, London.

Thompson, A. A.,(2006) Strategy, second edition, McGrow-Hill/IRWIN, Boston. 